
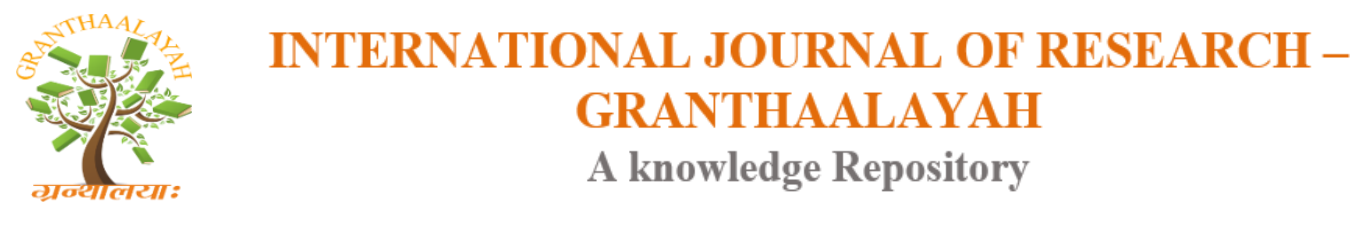

Social

\title{
USING BLOOM'S REVISED TAXONOMY TO ANALYZE READING COMPREHENSION QUESTIONS IN TEAM UP IN ENGLISH 1-3 AND GRADE 9 ENGLISH O-NET TESTS
}

\author{
Pornpimon Tangsakul $^{* 1}$, Wachiraporn Kijpoonphol ${ }^{2}$, Nguyen Duy Linh ${ }^{3}$, Lugsamee \\ Nuamthanom Kimura ${ }^{4}$ \\ ${ }^{*} 1,2,3$ Faculty of Liberal Arts, Ubon Ratchathani University, Thailand \\ ${ }^{4}$ School of Liberal Arts, Sukhothai Thammathirat Open University, Thailand
}

\begin{abstract}
The aim of the study was to use Bloom's Revised Taxonomy 2001 or Anderson \& Krathwohl's Taxonomy 2001 to analyze and compare the levels of reading comprehension questions found in reading parts of Team Up in English 1-3 and Grade 9 English O-NET Tests academic years 2013-2016. This study examined 416 reading comprehension questions from Team Up in English 1-3 and 65 reading comprehension questions from O-NET Tests academic years 20132016. Bloom's Revised Taxonomy 2001 was used as a framework for analyzing levels of reading comprehension questions. The findings showed that the levels of reading comprehension questions found in Team Up in English 1-3 and Grade 9 English O-NET tests academic years 2013-2016 were similar and were in low levels of reading comprehension questions.
\end{abstract}

Keywords: English Textbooks; O-NET Test; Levels of Reading Comprehension Questions; Bloom's Revised Taxonomy 2001; Anderson and Krathwohl's Taxonomy 2001.

Cite This Article: Pornpimon Tangsakul, Wachiraporn Kijpoonphol, Nguyen Duy Linh, and Lugsamee Nuamthanom Kimura. (2017). "USING BLOOM'S REVISED TAXONOMY TO ANALYZE READING COMPREHENSION QUESTIONS IN TEAM UP IN ENGLISH 1-3 AND GRADE 9 ENGLISH O-NET TESTS." International Journal of Research - Granthaalayah, 5(7), 31-41. https://doi.org/10.29121/granthaalayah.v5.i7.2017.2106.

\section{Introduction}

Educational evaluation is very necessary for instruction because it serves as an indicator of education success in all countries. According to Husprab (2014), educational evaluation reflects the quality of education in each country to ensure one's educational quality. As in Thailand, the national test is the test designed for evaluating students' learning quality according to the learning standards of the Basic Education Core Curriculum B.E. 2551 (Ministry of Education, 2008). This national test is known as Ordinary National Education Test (O-NET). The test results are used as information indicating educational quality of each level and individual students 
(Husprab, 2014). Moreover, the assessment results can indicate if schools have developed their educational quality to reach the standard or not (Nissaipan et al., 2015).

O-NET Tests designed according to National Institute of Education Testing Service-Public Organization of Thailand consists of eight subjects administered in Thai, and subject in English. The subjects are the same for grade 6, grade 9, and grade 12 students. They are listed as follows: foreign language, mathematics, science, social studies, Thai language, arts, health study and physical education, and occupation and technology (NIETS, 2015). The English subject consists of 50 multiple choice questions with four response options. The tests in academic years 20132015 consisted of four parts. Part 1 conversation consisted of 10 test items, Part 2 reading comprehension consisted of 15 test items, Part 3 writing consisted of 15 test items, and Part 4 miscellaneous consisted of 10 test items. However, in the academic year 2016 the pattern of the test blueprint was changed. Part 1 listening and speaking consisted of 15 test items, part 2 writing consisted of 15 test items, part 3 reading consisted of 20 test items (NIETS, 2015). It was clear that in the English O-NET Tests academic years 2013-2016, the biggest part was the reading part.

From the past four academic years, the English O-NET Test scores of Chief Executive Officer (CEO) Namkiang school-network group in Thailand were below the national mean scores, which were $27.42,25.29,26.79$, and 26.68 out of 100 respectively. The reason the students performed poorly and failed the O-NET Tests might be because they were not familiar with some reading texts and questions in the tests (Kaewmala, 2012). Since the textbooks were the basic tools in learning English, which helped students to learn more about useful types of questions that they may encounter in the national tests, the textbooks were considered as the important teaching and learning materials to prepare the students for the tests and were chosen by each school. However, in Sisaket Primary Educational Service Area Office 1, Sisaket province, Thailand, the schoolnetwork areas chose quite different English textbooks, the most popular textbook used in this area was Team Up in English.

According to Richards (2001), textbooks are a key component in most language teaching programs. In some situations, they serve as the basis for much of the language input learners receive and the language practice that occurs in the classroom (Krammer, 1985). Moreover, Ansary \& Babaii (2002) mentioned that using an English textbook is a framework which regulates and times the programs. In the eyes of learners, no textbook means no purpose. Without a textbook, learners think their learning is not taken seriously. In many situations, a textbook can serve as a syllabus. A textbook provides ready-made teaching texts and learning tasks. A learner without a textbook is out of focus. Additionally, the textbooks help the teacher to cut down the preparation time for classes and they provide the easier way to assign the homework based on the activities in the textbook (TESOL, 2017). This means that textbooks help provide the students the knowledge of the subject matters and also help the teachers as the instructional materials. An effective English textbook must have relevant reading passages followed by exercises and questions. The questions should assist students reading comprehension about what they read. By answering the questions, students should think critically and use different levels of thinking to get whole comprehension (Muchlis, 2015). 
To analyze the levels of reading comprehension questions, many researchers based their analysis on Bloom's Taxonomy 1956 and Bloom's Revised Taxonomy 2001 or Anderson and Krathwohl's Taxonomy 2001. Pohl (2000) explained Bloom's Revised Taxonomy 2001 in each level of question as follows. Remembering is the first stage of the thinking process. It occurs when the students describe, make lists, tell, and name aspects of the topic. Understanding level shows that the students understand what they have read. It occurs when they retell, infer, interpret, explain, predict, and outline knowledge. Applying is the stage of making use of knowledge in a new situation. It occurs when the students demonstrate, implement, carry out, or describe a similar situation. Analyzing is the process of breaking information into small parts. It happens when the students organize information and determine relationship between their previous knowledge and newly gained knowledge. Evaluating is to develop reason to support decision. It occurs when the students judge, choose, recommend, justify, critique about the text. Creating is the highest level. It occurs when the students design, construct, plan, and produce the new ideas (Pohl, 2000). Higher order thinking skills are reflected by the top three levels (Analyzing Evaluating and Creating); lower order thinking skills are reflected by the lower three levels (Remembering, Understanding, and Applying) (Anderson et al., 2001).

However, many researchers were interested in the levels of reading comprehension questions in tests and English textbooks and did the research differently. Khorsand (2009) studied cognitive levels of questions used by Iranian EFL teachers in advanced reading comprehension tests. The purpose of the study was to examine the cognitive levels of questions used in advanced reading comprehension tests by Iranian EFL teachers. In this study, 20 teachers were participated and 215 questions were categorized based on Bloom's taxonomy 1956. The result showed that most dominant question types was the knowledge level (54.21\%), followed by Comprehension level $(38.74 \%)$. On the other hand, the higher levels which are Analysis, Synthesis, and Evaluation were $0.47 \%, 2.33 \%$ and $1.39 \%$ respectively. From the result, it could be assumed that Iranian EFL teachers mainly taught and tested the students in the lowest cognitive levels.

In addition, Veeravagu et al. (2010) did a study on using Bloom's taxonomy 1956 to gauge students' reading comprehension performance. This study's aim was to investigate the relationship between the level of thinking in comprehension questions and the performance of the students. Bloom's taxonomy 1956 was used to indicate the level of questions the students gave in answering comprehension questions. The subjects were 50 diploma students who had similar academic background. A set of reading comprehension question with 35 multiple choice items were tested. The result showed that students did well in the questions on low level which were Knowledge, Comprehension, and Application. Only 66\% of students answered questions in Knowledge level correctly, 57.2\% for Comprehension level, 48.4\% for Analysis level, 47\% for Application level, 33.6\% for Synthesis, and 28\% for Evaluation level. It showed that the students had difficulties answering the questions in higher levels (Analysis, Synthesis, and Evaluation).

Similarly, Lan \& Chern (2010) studied on using Bloom's taxonomy 2001 to analyze reading comprehension questions on the SAET (Scholastic Achievement English Test) and the DRET (Department Required English Test) in Taiwan. This study aimed to examine the cognitive process levels and knowledge types on English reading comprehension tests of college entrance examinations from years 2002-2006. The data sources for analysis were reading passages and comprehension questions in SAET and DRET years 2002-2006. The total reading passages were 
36 and 140 for comprehension items which was 77 items in the SAETs and 63 items in DRETs. The study showed that in SAETs from years 2002-2006, 45.5\% were in Remember Factual Knowledge, which was the most frequent type of questions in the test. Likewise, the study showed that in DRETs years 2002-2006, the most frequent questions types found was Remember Factual Knowledge (36.5\%), followed by Understand Factual Knowledge (36.5\%), Understand Conceptual Knowledge (15.9\%), and Analyze Conceptual Knowledge (9.5\%). In the same way to SAET, it aimed to measure the students' abilities to understand facts, but less focus on analytical skills.

Abdelrahman (2014) analyzed the types and levels of questions in Grade 10 English language textbooks which are used in Jordan during the academic year 2012-2013. The purpose was to determine the distribution of the questions over the six levels of Bloom's Taxonomy 2001. The sample consisted of 655 questions from the textbooks. The results revealed that most of the questions were within the first two levels; Remembering and Understanding $(55.11 \%), 16.18 \%$ for Applying and less for the other levels $28.71 \%$. The results also revealed that the difference were in favor of the low level questions as the percentage was $51.9 \%$.

In 2015, Muchlis conducted a similar research to other researchers. However, the aim of the research was to investigate thinking order of reading comprehension questions in English textbook for young foresters of Forestry Vocational school of Samarinda. Content analysis method based on Bloom Taxonomy cognitive level as well as high and low order thinking was used to collect, analyze and classify reading questions. The findings showed that the reading comprehension questions covered all Bloom's Taxonomy cognitive levels. They were Knowledge, Comprehension, Application, Analysis, Synthesis and Evaluation. The most frequent questions appeared were in Knowledge and Comprehension levels. However, most of the questions were low order thinking and they had small number of high order thinking.

In sum, from the previous studies, most of them were done at the higher secondary educations using Bloom's Taxonomy 1956 and Bloom's Revised Taxonomy 2001. However, there were only few research studies on the comparison of reading comprehension questions in textbooks and the tests based on Bloom's Revised Taxonomy 2001. Therefore, this study aimed to answer this research question: What levels of reading comprehension questions can be found in Grade 9 English O-NET Tests academic years 2013-2016 and Team Up in English 1-3 in terms of similarities and differences? Based on Bloom's Revised Taxonomy 2001, the six levels of questions are: Remembering, Understanding, Applying, Analyzing, Evaluating, and Creating (Anderson et al., 2001).

\section{Sources of Data and Procedure}

\subsection{Sources of Data}

The data were taken from English textbooks used among the schools in the CEO Namkiang school-network area in Sisaket, Thailand for Grade 6-9 entitled "Team Up in English 1-3 Textbooks" written by F. Kavanagh, C.L. Moore, C.E. Morris, A. Smith and J. Cattunar and published in Thailand in 2012. The textbooks were used as source of data because they were most used among the schools in the CEO Namkiang school-network area in Sisaket, Thailand. 
Each textbook consists of 12 units. Only reading comprehension questions were analyzed in terms of levels. The total numbers of reading passages as a source of data from Team Up in English 1-3 were 66 reading passages, total numbers of reading comprehension questions were 416 questions.

The data were also taken from Grade 9 O-NET Tests academic years 2013-2016 designed by the National Institute of Educational Testing Service team. For Grade 9 English O-NET tests academic years 2013-2016, they were used to assess Grade 9 Thai students' English knowledge. The total numbers of reading passages as a source of data from Grade 9 O-NET Tests were 21 reading passages, total numbers of reading comprehension questions were 65 questions.

\subsection{Research Procedure}

First of all, a checklist was created based on Bloom's Revised Taxonomy 2001. The checklist then consisted of 10 columns: number; location; questions from the textbooks and tests; six levels of Bloom's Revised Taxonomy - Remembering, Understanding, Applying, Analyzing, Evaluating and Creating - and sample questions for each level; and question's keywords (See Appendix 7). The sample questions for each level were adapted from Delton (1986), Pohl (2000) and Anderson \& Krathwohl (2001) as illustrated in Appendix 1-6.

Next, the three textbooks and four O-NET Tests were read by one of the researchers. The reading comprehension questions were collected and typed in the third column of checklist. Then, the checklist, the tests and the textbooks were sent to two inter-raters to analyze. Meanwhile, the tests and the textbooks were analyzed by one of the researchers.

After that, the data from the three inter-raters was grouped. In the case of inconsistency, the inter-raters were consulted. Then, the idea and reasons were combined to make sure the finding was reliable. Then, the percentage of occurrence for each level was calculated.

\section{Results and Discussions}

The analysis of Grade 9 English O-NET Tests academic years 2013-2016 and Team Up in English 1-3 textbooks concerning the reading comprehension questions were presented as follows:

Table 1: Levels of Reading comprehension questions in Grade 9 English O-NET Tests Academic Years 2013-2016

\begin{tabular}{|c|c|c|c|c|c|c|c|}
\hline \multirow{2}{*}{$\begin{array}{c}\text { Test } \\
\text { years }\end{array}$} & \multirow{2}{*}{$\begin{array}{c}\text { No. of } \\
\text { Questions }\end{array}$} & \multicolumn{6}{|c|}{ Level of Questions } \\
\hline & & Remembering & Understanding & Applying & Analyzing & Evaluating & Creating \\
\hline 2013 & 15 & $\begin{array}{c}7 \\
46.67 \% \\
\end{array}$ & $\begin{array}{c}\mathbf{5} \\
\mathbf{3 3 . 3 3 \%} \\
\end{array}$ & - & $\begin{array}{c}3 \\
\mathbf{2 0} \% \\
\end{array}$ & - & 0 \\
\hline 2014 & 15 & $\begin{array}{c}9 \\
60 \%\end{array}$ & $\begin{array}{c}6 \\
40 \%\end{array}$ & - & - & - & - \\
\hline 2015 & 15 & $\begin{array}{c}9 \\
60 \%\end{array}$ & $\begin{array}{c}\mathbf{5} \\
\mathbf{3 3 . 3 3 \%}\end{array}$ & - & $\begin{array}{c}1 \\
6.67 \%\end{array}$ & - & - \\
\hline 2016 & 20 & $\begin{array}{c}2 \\
10 \%\end{array}$ & $\begin{array}{c}11 \\
55 \%\end{array}$ & $\begin{array}{c}1 \\
5 \%\end{array}$ & $\begin{array}{c}5 \\
25 \%\end{array}$ & $\begin{array}{c}1 \\
5 \%\end{array}$ & - \\
\hline Total & 65 & $\begin{array}{c}27 \\
41.54 \%\end{array}$ & $\begin{array}{c}27 \\
41.54 \%\end{array}$ & $\begin{array}{c}1 \\
1.54 \%\end{array}$ & $\begin{array}{c}9 \\
13.85 \%\end{array}$ & $\begin{array}{c}1 \\
1.54 \%\end{array}$ & - \\
\hline
\end{tabular}


Table 1 showed reading comprehension questions found in Grade 9 English O-NET Tests academic years 2013-2016. In the test year 2013, there were only three levels of questions found which were Remembering (46.67\%), Understanding (33.33\%), and Analyzing (20\%) from the most frequency to the least found in the academic year 2014. In the test academic year 2014, Remembering was the most level of questions found with $60 \%$, followed by Understanding with $40 \%$. In the academic year 2015, the most level of questions found was Remembering (60\%), and followed by Understanding (33.33\%) and Analyzing (6.67\%). In the academic year 2016, there were more various levels of questions, except Creating. The most frequency level of questions found in this year was Understanding (55\%), followed by Analyzing (25\%) and Remembering (10\%). Applying and evaluating were the least found with 5\% for each.

In sum, the most frequency of levels of questions found were Remembering and Understanding with $41.54 \%$ each. Moreover, only these two levels - Remembering and Understanding could be found in every test from academic years 2013-2016. Nevertheless, Creating which is the highest level of Bloom's Revised Taxonomy 2001 did not appear any test years.

Table 2: Levels of Reading Comprehension Questions in Team Up in English 1-3 Textbooks

\begin{tabular}{|c|c|c|c|c|c|c|c|}
\hline \multirow{2}{*}{ Textbooks } & \multirow{2}{*}{$\begin{array}{c}\text { No. of } \\
\text { Questions }\end{array}$} & \multicolumn{6}{|c|}{ Level of Questions } \\
\hline & & Remembering & Understanding & Applying & Analyzing & Evaluating & Creating \\
\hline $\begin{array}{l}\text { Team Up } \\
\text { in Eng } 1\end{array}$ & 87 & $\begin{array}{c}70 \\
80.46 \%\end{array}$ & $\begin{array}{c}17 \\
19.54 \%\end{array}$ & $-2 x-2-1=0$ & 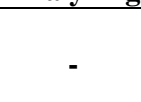 & 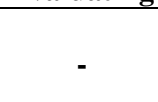 & 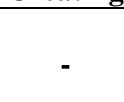 \\
\hline $\begin{array}{l}\text { Team Up } \\
\text { in Eng } 2\end{array}$ & 102 & $\begin{array}{c}89 \\
87.26 \%\end{array}$ & $\begin{array}{c}11 \\
10.72 \%\end{array}$ & - & $\begin{array}{c}2 \\
1.96 \%\end{array}$ & - & - \\
\hline $\begin{array}{l}\text { Team Up } \\
\text { in Eng } 3\end{array}$ & 227 & $\begin{array}{c}137 \\
60.35 \%\end{array}$ & $\begin{array}{c}42 \\
18.50 \%\end{array}$ & $\begin{array}{c}14 \\
6.17 \%\end{array}$ & $\begin{array}{c}11 \\
4.85 \%\end{array}$ & $\begin{array}{c}21 \\
9.25 \%\end{array}$ & $\begin{array}{c}2 \\
0.88 \%\end{array}$ \\
\hline Total & 416 & $\begin{array}{c}296 \\
71.15 \%\end{array}$ & $\begin{array}{c}70 \\
16.83 \%\end{array}$ & $\begin{array}{c}14 \\
3.37 \%\end{array}$ & $\begin{array}{c}13 \\
3.13 \%\end{array}$ & $\begin{array}{c}21 \\
5.05 \%\end{array}$ & $\begin{array}{c}2 \\
0.48 \%\end{array}$ \\
\hline
\end{tabular}

Table 2 showed reading comprehension questions found in Team Up in English 1-3 textbooks compatibility with Bloom's Revised Taxonomy 2001. Most level of questions found in Team Up in English 1-3 was Remembering (71.15\%), followed by Understanding (16.83\%), Evaluating (5.05\%), Applying (3.37\%), Analyzing (3.13\%), and Creating (0.48\%). In other word, majority of percentages were in low levels of questions, while in high levels of questions could be found altogether only $8.66 \%$. Evaluating had the highest percentage among high levels of questions. The similarity among Team Up in English 1-3 was that Remembering and Understanding appeared in all of them. However, Analyzing level started to appear in Team Up in English 2-3. Moreover, Team up in English 3 covered every level of questions.

Table 3: Levels of Reading Comprehension Questions in Grade 9 English O-NET Tests Academic Years 2013-2016 and Team Up in English 1-3 Textbooks

\begin{tabular}{|c|c|c|c|c|c|c|c|}
\hline Tests/ & No. of \\
Textbooks & Questions & \multicolumn{7}{|c|}{ Level of Questions } \\
\cline { 3 - 8 } O-NET & Remembering & Understanding & Applying & Analyzing & Evaluating & Creating \\
2013-2016 & 65 & $\begin{array}{c}27 \\
41.54 \%\end{array}$ & $\begin{array}{c}27 \\
41.54 \%\end{array}$ & $\begin{array}{c}1 \\
1.54 \%\end{array}$ & $\begin{array}{c}9 \\
13.85 \%\end{array}$ & $\begin{array}{c}1 \\
1.54 \%\end{array}$ & - \\
\hline $\begin{array}{c}\text { Team Up } \\
\text { in Eng 1-3 }\end{array}$ & 416 & $\begin{array}{c}296 \\
71.15 \%\end{array}$ & $\begin{array}{c}70 \\
16.83 \%\end{array}$ & $\begin{array}{c}14 \\
3.37 \%\end{array}$ & $\begin{array}{c}13 \\
3.13 \%\end{array}$ & $\begin{array}{c}21 \\
5.05 \%\end{array}$ & $\begin{array}{c}2 \\
0.48 \%\end{array}$ \\
\hline
\end{tabular}


Table 3 showed the comparison between reading comprehension questions found in Grade 9 English O-NET Tests academic years 2013-2016 and Team Up in English 1-3 textbooks. Remembering was the most frequency level of questions found Team Up in English 1-3 with 71.15; while in O-NET Tests Remembering and Understanding offered the same percentage with 41.54\%. However, in Team Up in English 1-3, Understanding was the second most frequency level with $16.83 \%$. The least frequency levels found in the tests were Applying and Evaluating with $1.54 \%$ each; while Creating $(0.48 \%)$ was the least of level of questions found in the textbooks only.

In sum, most levels in both the tests and the textbooks were in low level of questions which were Remembering and Understanding. However, in high levels of questions, Creating level was not found in any test years.

To answer the research question, "What levels of reading comprehension questions can be found in Grade 9 English O-NET Tests academic years 2013-2016 and Team Up in English 1-3 in terms of similarities and differences?", the results showed that the most frequency of levels of questions found in O-NET Tests were Remembering and Understanding with $41.54 \%$ each. Moreover, only these two levels - Remembering and Understanding could be found in every test from academic years 2013-2016. Similarly with Team Up in English 1-3, most levels of reading comprehension questions found were Remembering (71.15\%) and Understanding (16.83\%). However, the only difference between the O-NET Tests and the textbooks was Creating. This highest level of question appeared only in Team Up in English 3.

From the analysis on levels of reading comprehension questions in the tests and the textbooks in this study, the results were similar with the previous studies. Moreover, the results in this study were also similar with Khorsand (2009), Veeravagu et al. (2010), Lan \& Chern (2010) and Abdelrahman (2014) in term of levels of questions based on Bloom's taxonomy 1956 and Bloom's Revised Taxonomy 2001. The results showed that most reading comprehension questions found were in low levels which were Knowledge (Remembering), and Comprehension (Understanding). On the other hand, higher levels, which were Analysis (Analyzing), Evaluation (Evaluating), and Synthesis (Creating), were also found but in the small number of percentages. The results from previous studies and this study can be used to mention that most English textbooks and the tests in secondary educations provided low levels of questions which not much help develop students' higher thinking skills.

For levels of reading comprehension questions found in Grade 9 English O-NET Tests academic years 2013-2016 based on Bloom's Revised Taxonomy 2001, Remembering and Understanding were most found in every year of the tests. It means that O-NET Tests academic years 20132016 most provided the reading comprehension questions in lower levels. However, Analyzing which was the lowest of higher level of Bloom's taxonomy was presented in academic year 2013, 2015, and 2016, except for year 2014. Moreover, in the academic year 2016, Evaluating, which was in higher level, was presented in reading comprehension questions. From the data, it can be assumed that the test writers tended to provide more high level of questions at present years. However, low level of reading comprehension questions, which were Remembering and Understanding, remained the majority number of questions in the tests. Similarly with the textbooks, the majority numbers of reading comprehension questions were in Remembering and 
Understanding levels. However, Team Up in English 3 was the only textbook that presented every level of questions based on Bloom's Revised Taxonomy 2001, while only Remembering and Understanding was found in Team Up in English 1. It showed that Team Up in English 3 could help prepare the students to be familiar with the levels of questions in the tests better than Team Up in English 1 and 2.

\section{Conclusions \& Recommendations}

This research study has attempted to find the levels of reading comprehension questions found in Grade 9 English O-NET Tests academic years 2013-2016 and Team Up in English 1-3 textbooks. It was found that the levels of reading comprehension questions found in Grade 9 English O-NET Tests academic years 2013-2016 and Team Up in English 1-3 were in Remembering and Understanding levels. However, the highest level of questions, which was Creating, was found only in Team Up in English 3 but in the low percentage.

The results can be used as a guideline for educational decision-makers, head masters and English teachers who wish to modify their practice and to choose new textbooks in a way as to achieve higher levels of learning objectives and higher scores of O-NET Tests.

\section{Pedagogical Implication}

Since Grade 9 Thai students have to take the O-NET Tests every year, getting familiar with the type of questions can help them do well on the tests. The teachers can make use of reading comprehension questions in the textbook, especially in Team Up in English 3, to help the students familiar with the questions in the tests since the most frequency levels of reading comprehension questions found were the same. Moreover, the teachers can make use of the analysis by providing extra materials in higher levels of questions to extend the students' higher thinking skills, which they were lack in the textbooks.

\section{Appendices}

Sample Questions Adapted from Delton (1986), Pohl (2000) and Anderson et al. (2001) for Analyzing Levels of Reading Comprehension Questions of Bloom's Revised Taxonomy 2001

\section{Appendix 1: Samples Questions of Remembering Level}

\begin{tabular}{|c|c|c|}
\hline Level & Verbs & Sample questions/ statement stems \\
\hline Remembering & $\begin{array}{l}\text { Choose } \\
\text { Define, Describe, Duplicate } \\
\text { Find } \\
\text { List, Label, Locate } \\
\text { Match } \\
\text { Name } \\
\text { Omit, Recall, Recognize, } \\
\text { Reproduce Relate } \\
\text { State, Select, Show, Spell } \\
\text { Tell } \\
\text { Underline } \\
\text { Write }\end{array}$ & $\begin{array}{l}\text { What?, What is...? What does it mean?, What is the best } \\
\text { one?, What happened after?, What do you remember } \\
\text { about...?, What would you choose...? } \\
\text { Where?, Where is...? How?, How is (are)...?, How much?, } \\
\text { How many?, How did ... happen?, How would you } \\
\text { describe...?, How would you define...?, How would you } \\
\text { identify...?, How would you recognize...?, How would you } \\
\text { outline...?, Who?, Who was...?, Why did...?, Who were the } \\
\text { main...? Who spoke to...?, When?, When did...? Recall...? } \\
\text { Which one?, Which is true or false?, Can you name all } \\
\text { the...?, Describe what happens when...? } \\
\text { List the... in order. }\end{array}$ \\
\hline
\end{tabular}




\section{Appendix 2: Samples Questions of Understanding Level}

\begin{tabular}{|c|c|c|}
\hline Level & Verbs & Sample questions/ statement stems \\
\hline Understanding & $\begin{array}{l}\text { Calculate, Compare, } \\
\text { Classify, Contrast, } \\
\text { Describe, Discuss, } \\
\text { Distinguish, Demonstrate, } \\
\text { Expand, Explain, Extend, } \\
\text { Identify, Interpret, Illustrate, } \\
\text { Infer, Interpret, } \\
\text { Locate, Outline, } \\
\text { Predict, } \\
\text { Report, Restate, Relate, } \\
\text { Rephrase, Show, } \\
\text { Summarize, Translate }\end{array}$ & $\begin{array}{l}\text { How would you classify the type of...?, How would you } \\
\text { compare or contrast...?, How would you rephrase the } \\
\text { meaning...? How would you summarize...? How would you } \\
\text { clarify the meaning...?, How would you differentiate } \\
\text { between...?, How would you generalize...?, How would } \\
\text { you express...?, How would you identify...?, How can you } \\
\text { describe...?, What facts or ideas show...? What can you say } \\
\text { about...?, What does this mean?, What would happen if...?, } \\
\text { What expectations are there? What are they saying?, What } \\
\text { seems to be...?, What seems likely?, What restrictions } \\
\text { would you add?, What can you infer from...?, What did you } \\
\text { observe...?, What is the main idea of ...? }\end{array}$ \\
\hline
\end{tabular}

\section{Appendix 3: Samples Questions of Applying Level}

\begin{tabular}{|c|c|c|}
\hline Level & Verbs & Sample questions/ statement stems \\
\hline Applying & $\begin{array}{l}\text { Apply, } \\
\text { Build, } \\
\text { Classify, Construct, } \\
\text { Complete, Choose, } \\
\text { Demonstrate, Dramatize, } \\
\text { Develop, } \\
\text { Examine, Execute, } \\
\text { Illustrate, Implement, } \\
\text { Identify, Interview, } \\
\text { Make use of, Model, } \\
\text { Organize, } \\
\text { Practice, Plan, } \\
\text { Show, Solve, Select, } \\
\text { Use, Utilize }\end{array}$ & $\begin{array}{l}\text { How would you use...?, How would you solve... using what } \\
\text { you've learned?, How would you explain...?, How would } \\
\text { you present...?, How would you develop... to present...?, } \\
\text { How would you demonstrate...?, How would you } \\
\text { modify...?, How could you develop...?, How would you } \\
\text { alter...to...?, What approach would you use to...?, What } \\
\text { would result if...?, What elements would you choose to } \\
\text { change...?, What questions would you ask in an interview } \\
\text { with...? What do you think could have happened next?, } \\
\text { What was the main idea...?, What questions would you ask } \\
\text { of ...?, What actions would you take to perform...?, What } \\
\text { other way would you choose to...?, What would the result } \\
\text { be if...?, What examples can you find that...? } \\
\text { Who do you think...?, Which factors would you change if } \\
\ldots . \text { ?, Why does... work?, Can you group by characteristics } \\
\text { such as...?, Tell what would happen if..., Tell how much } \\
\text { change there would be if..., Identify the results of..., } \\
\text { Illustrate the..., Write in your own words... }\end{array}$ \\
\hline
\end{tabular}

\section{Appendix 4: Samples Questions of Analyzing Level}

\begin{tabular}{|c|c|c|}
\hline Level & Verbs & Sample questions/ statement stems \\
\hline Analyzing & $\begin{array}{lr}\text { Advertise, } & \text { Analyze, } \\
\text { Appraise, } & \text { Attribute, } \\
\text { Assume, } & \\
\text { Categorize, } & \text { Compare, } \\
\text { Contrast, } & \text { Classify, } \\
\text { Conclude, } & \text { Differentiate, } \\
\text { Distinguish, } & \text { Discover, } \\
\text { Dissect, Divide, } & \\
\text { Examine, Function, } \\
\text { Identify, Infer, Investigate, } \\
\text { Infer, Inspect, } \\
\text { List, } \\
\text { Motive, } \\
\text { Organize, Outline, } \\
\text { Separate, Simplify, Survey, } \\
\text { Test, Take part in }\end{array}$ & $\begin{array}{l}\text { What are parts of features of...?, What is the theme...?, } \\
\text { What inferences can you make...?, What is the relationship } \\
\text { between...?, What is the function of ...?, What's fact? } \\
\text { Opinion?, What assumptions...?, What statement is } \\
\text { relevant?, What is the conclusion?, What does the author } \\
\text { believe/assume?, What ideas apply?, What ideas justify the } \\
\text { conclusion?, What's the main idea?, What might the ending } \\
\text { have been?, What do you see as other possible outcomes?, } \\
\text { What were some of the motives behind...?, What was the } \\
\text { turning point?, What are some of the problems of ...?, What } \\
\text { explanation do you have for...?, What is the analysis of...?, } \\
\text { What can you infer...?, What ideas validate...?, What can } \\
\text { you point out about...?, What is the problem with ...? } \\
\text { Which events could not have happened? } \\
\text { How is ... related to...?, How can you classify...?, How is } \\
\ldots \text { similar to...?, How can you compare the different }\end{array}$ \\
\hline
\end{tabular}




\begin{tabular}{|l|l|l|}
\hline & $\begin{array}{l}\text { parts...?, How is ... connected to...?, How can you sort the } \\
\text { parts...?, Why did...changes occur?, Why do you think...?, } \\
\text { Can you explain what must have happened when...?, Can } \\
\text { you distinguish between...? }\end{array}$ \\
\hline
\end{tabular}

Appendix 5: Samples Questions of Evaluating Level

\begin{tabular}{|c|c|c|}
\hline Level & Verbs & Sample questions/ statement stems \\
\hline Evaluating & 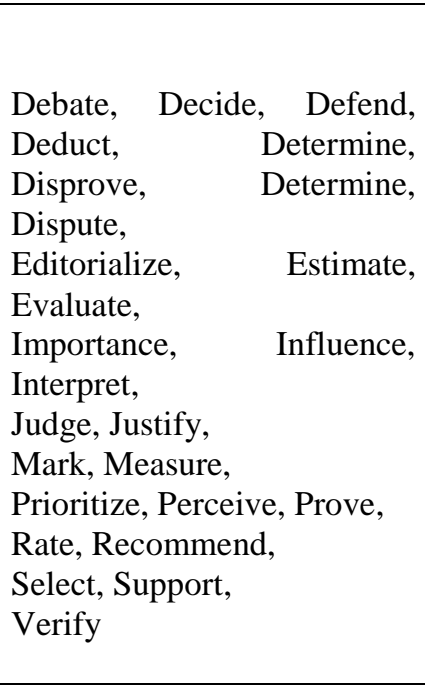 & $\begin{array}{l}\text { What influence will...have on our lives?, What are the pros } \\
\text { and cons of...?, What are the alternatives?, What criteria } \\
\text { would you use to access...?, What data was used to } \\
\text { evaluate...?, What choice would you have made...?, What is } \\
\text { the most important...?, What would you suggest...?, What } \\
\text { information would you use to prioritize...?, How would you } \\
\text { prove or disprove...?, How would you rate the ...?, How } \\
\text { could you determine...?, How would you prioritize...?, How } \\
\text { would you compare the ideas...?, How would you compare } \\
\text { the people? How would you justify...? How would you } \\
\text { explain...?, How would you have handled...?, How would } \\
\text { you feel if...?, How effective are...?, How would you } \\
\text { determine the facts...?, How would you grade...?, How } \\
\text { could you verify...?, Why is... of value? Which is more } \\
\text { important, logical, valid, appropriate? Would it be better } \\
\text { if...?, Do you think...is a good or bad thing? Do you } \\
\text { believe...?, Is there a better solution to...? }\end{array}$ \\
\hline
\end{tabular}

\section{Appendix 6: Samples Questions of Creating Level}

\begin{tabular}{|c|c|c|}
\hline Level & Verbs & Sample questions/ statement stems \\
\hline Creating & $\begin{array}{l}\text { Adapt, Build, Change, } \\
\text { Combine, Compare, } \\
\text { Compose, Construct, Create, } \\
\text { Choose, Compile, } \\
\text { Design, Develop, Discuss, } \\
\text { Delete, Design, Devise, } \\
\text { Elaborate, Estimate, } \\
\text { Formulate, Generate, } \\
\text { Hypothesize, Happen, } \\
\text { Imagine, Improve, Invent, } \\
\text { Make up, Maximize, } \\
\text { Minimize, Modify, } \\
\text { Original, Originate, } \\
\text { Plan, Predict, Propose, } \\
\text { Solve, Suppose, Test }\end{array}$ & $\begin{array}{l}\text { How would you improve...?, How would you test...?, How } \\
\text { would you estimate the results for ...?, How many ways can } \\
\text { you...?, How would you explain the reason...?, How would } \\
\text { you generate a plan to...?, How would you portray...?, } \\
\text { How would you compile the facts for...?, How would you } \\
\text { elaborate on the reason...?, How else would you...?, } \\
\text { What would happen if...?, What alternative would you } \\
\text { suggest for...?, What changes would you make to revise...?, } \\
\text { What could you invent...?, What facts can you gather...?, } \\
\text { Why don't you devise your own way to...?, If you had } \\
\text { access to all resources how would you deal with...? } \\
\text { Construct a new model that would change... } \\
\text { Predict the outcome of... }\end{array}$ \\
\hline
\end{tabular}

Appendix 7: Checklist for Analyzing Reading Comprehension Questions

\begin{tabular}{|c|c|c|c|c|c|c|c|c|c|}
\hline No. & Location & Questions & Remembering & Understanding & Applying & Analyzing & Evaluating & Creating & Keywords \\
\hline 1 & $\begin{array}{c}\text { Team Up } \\
1, \text { p.98 }\end{array}$ & $\begin{array}{c}\text { What are } \\
\text { these } \\
\text { famous } \\
\text { people } \\
\text { wearing? }\end{array}$ & $\checkmark$ & - & - & - & - & - & \\
\hline 2 & $\begin{array}{c}\text { Team Up } \\
\text { What } .65\end{array}$ & $\begin{array}{c}\text { What } \\
\text { doesn't } \\
\text { she like? }\end{array}$ & - & $\checkmark$ & - & - & - & - & \\
\hline 3 & $\begin{array}{c}\text { Team Up } \\
3, \text { P.13 }\end{array}$ & $\begin{array}{c}\text { Which } \\
\text { two places } \\
\text { did she } \\
\text { isisit? }\end{array}$ & $\checkmark$ & - & - & - & - & - & which \\
\hline
\end{tabular}




\begin{tabular}{|c|c|c|c|c|c|c|c|c|c|}
\hline 4 & $\begin{array}{c}\text { Team Up } \\
3, \text { p.38 }\end{array}$ & $\begin{array}{c}\text { How } \\
\text { many } \\
\text { films has } \\
\text { she made? }\end{array}$ & $\checkmark$ & - & - & - & - & - & \\
\hline
\end{tabular}

\section{References}

[1] Abdelrahman, M. S. H. B. (2014). An analysis of the tenth grade English language textbooks questions in Jordan based on the revised edition of Bloom's taxonomy. In Journal of Education and Practice. 5(8), pp.139-151.

[2] Anderson, L. W, Krathwohl, D. R., Airasian, P. W., Cruikshank, K. A., Mayer, R. E., Rintrich, P. R., Raths, J. \& Wittrock, M. C. (2001). A taxonomy for learning, teaching, and assessing: A revision of Bloom's Taxonomy of educational objectives. Allyn \& Bacon. Boston, MA (Pearson Education Group).

[3] Ansary, H., \& Babaii, E. (2002). CEN 2015 Analysis of English textbooks and supplementary reading books. In Share My Passion, Share My Thoughts. Retrieved May 1, 2017.

[4] Husprab, P. (2014). The educational development through O-NET Test scores (Master's thesis). Unpublished.

[5] Kaewmala. (2012). Thai education failures - Part 1: Ridiculous O-NET questions. Retrieved: June 19, 2017, from: http://thaiwomantalks.com/2012/02/26/the-sorry-state-of-thai-educationpart-1-ridiculous-o-net-questions/

[6] Khorsand, N. (2009). Cognitive levels of questions used by Iranian EFL teachers in Advanced Reading Comprehension Tests. Master's degree. Iran.

[7] Krammer, H. P. M. (1985). The textbook as classroom context variable. Teaching and Teacher Education, v. 1(4), $273-278$.

[8] Lan, W. H. \& Chern, C. L. (2010). Using revised Bloom's Taxonomy to analyze reading comprehension questions on the SAET and the DRET. Contemporary Educational Research Quarterly, 18(3), 165-206.

[9] Ministry of Education (2008). The basic education core Curriculum B.E. 2551 (A.D. 2008). Bangkok, Thailand: Ministry of Education. Retrieved May 1, 2017, from http://www.act.ac.th/document/1741.pdf

[10] Muchlis (2015). An analysis of thinking order of reading comprehension questions in English textbook for young foresters of Forestry Vocational School of Samarinda. Journal Nalar Pendidikan, 3(1). 314-316.

[11] National Institute of Educational Testing Service (NIETS). (2015). Retrieved from http://www.niets.or.th/uploads/content_pdf/7-2558-.pdf.

[12] Nissaipan, N. et al. (2015). The study of O-NET Tests by Supervision, Monitoring and Evaluation for Educational Group.

[13] Pohl, M. (2000). Learning to think, thinking to learn: Models and strategies to develop a classroom culture of thinking. Cheltenham, Vic.: Hawker Brownhow.

[14] Richards, J. C. (2001). The role of textbooks in a language program. Cambridge, UK: Cambridge University Press.

[15] TESOL: Using textbooks effectively (2017, April 29). In Ontesol. Retrieved June 4, 2017, from http://how-to-teach-english.ontesol.com/tesol-using-textbooks-effectively/

[16] [16] Veeravagu, J., Muthusamy, C., Marimuthu, R., \& Subrayan, A. (2010). Using Bloom's Taxonomy to gauge students' reading comprehension performance. Canadian Social Science, 6(3), 205-212.

\footnotetext{
*Corresponding author.

E-mail address: pornpimontang@gmail.com
} 